\title{
Anglo-Russian Rivalry in the American Arctic, Eighteenth to Mid-Nineteenth Centuries
}

\author{
Andrei Val'terovich Grinëv \\ Peter the Great St. Petersburg Polytechnic University
}

\begin{abstract}
Attempts to penetrate into the Arctic coast of the North American continent were made from the west and from the east beginning in the eighteenth century. From the east the main role was played by the British, from the west by the Russians. The tsarist government and the Siberian authorities sent several research expeditions to the Bering Strait area, where the southern border of the Arctic lies. The First Kamchatka Expedition of Vitus Bering, which in 1728 passed through the strait between Asia and America, was the most famous. The British showed interest in this region much later. The first explorer to do so was the eminent British seafarer James Cook who passed through Bering Strait in 1778, causing considerable alarm in St. Petersburg, which feared British penetration into the "backyard" of the Russian Empire. However, after the Cook expedition the British did not appear in the Arctic waters of Alaska for several decades for various economic and political reasons.Anglo-Russian rivalry only resumed in the American Arctic in the 1820s, when several exploratory maritime expeditions were sent to the Bering and Chukchi Sea areas. These were replaced after the second half of the 1830s by land expeditions that were sent to the Arctic territories of Alaska by competing fur-trading companies: the Russian-American Company (RAC), which operated in Alaska from 1799, and the British Hudson's Bay Company (HBC) from neighbouring Canada. Subsequently, up until the sale of Alaska to the United States in 1867, Anglo-Russian rivalry was embodied in the form of trade competition between RAC and HBC agents.
\end{abstract}

The Northern Review 49 (2020): 167-190 
The American Arctic was rather late in becoming an object of international rivalry. The Russians and the British played the main roles as competitors. Starting in the sixteenth century, the latter tried to penetrate through from the Atlantic Ocean to Bering Strait, in order to then reach the rich eastern countries of Japan and China (i.e., the expeditions of John Davis, Henry Hudson, Thomas Button, and others). But all of these attempts were unsuccessful. For their part, the Russians went to the American Arctic from the west after Ataman Yermak's famous campaign to Western Siberia from 1581 to 1585 . They gradually opened up the northern fringes of Siberia, moving to the shores of Alaska. The first references to the American Arctic, which borders Chukotka across Bering Strait, appeared in Siberia as early as the seventeenth century when detachments of Cossacks, merchants, and promyshlenniki (hunters of fur-bearing animals) reached the Kolyma and Anadyr rivers. In 1648 Cossack Semën Dezhnëv and a clerk of the merchant Usov, Fedot Popov, set off from the Kolyma in seven kochi (small Pomor sailing-rowing ships) to the mouth of the Anadyr. Popov circumnavigated the Chukchi Peninsula from the east, thus passing as the first Europeans through Bering Strait (Efimov, 1948, pp. 50-51; Russkaya Tikhookeanskaya epopeya, 1979, pp. 77-79).

At that time the American Arctic was not viewed as an object of Anglo-Russian rivalry. Neither side simply had any precise information about the region: the English abandoned attempts to go through the Northwest Passage as early as the beginning of the seventeenth century. The Russians had rather vague ideas about the "Great Land" lying beyond the Chukchi Peninsula. The Chukchi and American Indigenous peoples (Yup'ik and Inupiat) living near the Bering Sea reported to them from time to time. Alaska appeared for the first time on Russian geographic maps at the beginning of the eighteenth century (Postnikov, 2000, pp. 24-25).

All these data attracted the attention of the central authorities, who sent a couple of research expeditions to that region of Northeast Asia: the Great Kamchatka Detachment in 1716 and the expedition of geodesists Ivan Evreinov and Fëdor Luzhin in 1719-1722. The task of the members was to study Kamchatka, Chukotka, and the "mainland" nearby, that is, Alaska. But the first expedition ended unsuccessfully, and the second 
also failed to reach the shores of the American Arctic (Efimov, 1948, pp. 132-134; Russkie ekspeditsii, 1984, pp. 30-33, 45; Polevoi, 1997, pp. 49-50).

Dissatisfied with the results of these expeditions, on 23 December 1724 Tsar Peter I gave the order to the Admiralty College to organize the First Kamchatka Expedition. And just two weeks later Captain Vitus Bering, named its head, received imperial instructions. In them the tsar ordered two sailing vessels, constructed in Kamchatka, to be sent along the shore of the land "which goes north." They were to investigate the region where the land converges with America, and after that to go to the nearest city of European possessions in the New World (Russkie, 1984, pp. 35-36). The confusing and vague meaning of Peter's instructions subsequently brought arguments among historians about where Bering was supposed to sail-north to the strait subsequently named after him, or east to the shores of America. Bering himself chose the northern direction, setting off in the summer of 1728 along the coast of Kamchatka and Chukotka in the small single-mast boat Sv. Gavriil. He passed through Bering Strait, encountering along the way the large St. Lawrence Island (Sivuqaq). Going a little farther than $67^{\circ}$ north latitude in the Arctic Ocean, he decided on 15 August to return to Kamchatka to winter over (Russkie, 1984, p. 86).

On the whole, the First Kamchatka Expedition had little success. It "discovered" only St. Lawrence Island and Ratmanova Island (Big Diomede, Imaqliq) in Bering Strait. It did not firmly prove the existence of a strait between Asia and America, since the sailors did not see the shores of Alaska because of the thick fog. Therefore, the ultimate Russian discovery of the American Arctic occurred only in 1732. At that time the boat Sv. Gavriil, under the command of geodesist Mikhail Gvozdev and navigator's assistant Ivan Fëdorov, approached the American mainland at Seward Peninsula. On the Alaskan shore the travellers saw coniferous forests, a multitude of deer, and dwellings of the local Indigenous people (Inupiat). One of the Eskimos sailed out in a kayak (baidarka) to the boat. Curiously, the Eskimo understood the Chukchi language of the interpreter well. And he could correctly determine the direction to Kamchatka, which the Russians asked him, pretending to be lost at sea and starving. Ultimately the boat took the return route and arrived safely in its home harbour (Russkaya, 1979, pp. 150-155; Russkie, 1984, pp. 106-110; Efimov, 1948, pp. 159-174). 
Despite the real significance of the Gvozdev-Fëdorov expedition's geographic attainments, it did not have any practical consequences. Its members' reports did not attract the attention of the Siberian leadership and became buried in archives and offices. Russian promyshlenniki (trappers and traders) and merchants thus did not use the shortest route from Asia to America through the islands of Bering Strait. Their movement into the New World passed much farther south along the chain of Aleutian Islands (Unangam Tanangin) but was connected not with the voyage of Fëdorov-Gvozdev but rather with the Second Kamchatka Expedition of V.I. Bering and A.I. Chirikov. In 1741 they encountered the fur-rich land and islands of Southeast and South Alaska as well as the chain of Aleutian and Commander islands.

It is interesting that simultaneously with this expedition, the Englishman Christopher Middleton undertook another unsuccessful attempt to find a Northwest Passage (Barr, 2005, pp. 1294). His failure again dampened, for a long time, the English desire to reach the Pacific Ocean through the Canadian Arctic and Bering Strait. Incidentally, after completion of the Kamchatka expeditions, the American Arctic no longer attracted the serious attention of the Russians. Of course in the mid-1760s the commander of the Anadyr Fort, Lieutenant Colonel Friedrich (Fëdor) Plenisner, collected information about Alaska and for this purpose sent off the baptized interpreter (half Koryak, half Chukchi) Cossack Nikolai Daurkin to survey Chukotka. He had a successful visit to St. Lawrence Island, along with the Chukchi, in 1763-1764. In addition, Plenisner initiated a little-known maritime expedition under the command of Lieutenant Johann (Ivan) Sindt, who in the summer of 1766 studied the waters of the Pacific Ocean in the region of Bering Strait, sailed near St. Lawrence Island, and encountered small St. Matthew Island (Russkie, 1989, pp. 53-54; Postnikov, 2000, pp. 86-87).

Another fifteen years passed before the American Arctic again attracted the attention of the tsarist government and Siberian authorities. In 1778-1779 two ships of the round-the-world expedition by the famous British mariner James Cook, who earlier had studied and mapped the outline of Alaska and several Aleutian Islands, twice passed through Bering Strait into the northern Arctic Ocean. Cook and his companions visited the shores of North Alaska and Chukotka, where they encountered the local residents. The English also visited Petropavlovsk-Kamchatski, 
Kamchatka (Kuk, 1971, pp. 307-408, 486-526, 553-565). During his voyage Cook gave English names to a multitude of places he saw on the map. This included St. Matthew Island, which-confident that it was unknown to the Russians-he labelled "Gore Island" in honour of his first assistant. Thereby he made indirect claim of the British crown to newly discovered lands (Kuk, 1971, p. 387).

Cook's voyage initiated, though not very intensely, Anglo-Russian rivalry for the American Arctic. The appearance of the English at the "back door" of the Russian Empire seriously alarmed St. Petersburg and Siberian authorities, since before this no one had challenged Russia in the North Pacific. Russia became so worried by Cook's voyage that in 1779 it sent the Cossack sotnik (commander of 100 men) Ivan Kobelev to Bering Strait for reconnaissance. After visiting Chukotka and the Diomede Islands (Inaliq), he reported, according to the words of the local Chukchi and Eskimos, that in the American land on the Khevren (Kheuveren) River at the Kymgovei ostrozhek (fort) allegedly "Russian people are in residence" who possess books, write, worship icons, and in distinction from the natives wear thick beards (Efimov, 1948, pp. 148-149, 228-233). Kobelev wanted to go to his compatriots, but the yasak (tribute) paying Chukchi forbade the Eskimos who inhabited the Diomede Islands to accompany him to the Alaskan shore, fearing the reprisal of the Russian leadership if he were taken prisoner there or killed. In fact, the Chukchi obviously feared losing their position in the intermediary trade in Alaskan furs.

In its turn the tsarist government organized, though with a substantial delay, a secret government expedition from 1785 to 1795 under the leadership of Joseph (Iosif) Billings, a member of the Cook expedition who had gone into the Russian service. Members of the expedition visited the Aleutian Islands, mainland Alaska, and the northwest coast in Bering Strait in 1791. There they encountered local Indigenous people (Inupiat) who convincingly requested Billings's defense from attacks by aggressive Chukchi. The Chukchi carried out devastating raids on their villages annually, coming in baidary (large skin boats) across the Bering Strait (Russkie, 1989, pp. 292-293; Sarychev, 1952, pp. 179-181). However, when Billings later submitted the petition about military protection of the Alaskan Eskimos, it was rejected by the Irkutsk governor general under the pretext of inexpediency of excessive financial expenses and the difficulty of 
supplying a military detachment in such a remote region (Russkaya, 1979, pp. 399-400).

A month and a half before Billings's arrival in the Bering Strait region, the Cossack sotnik Ivan Kobelev and interpreter Nikolai Daurkin again visited there. Billings himself had sent them to Cape Dezhnëv in 1790. Having gone with Chukchi across Bering Strait, they spent only a few days on American soil before returning to Chukotka (Efimov, 1948, pp. 148-149, 228-233). Incidentally, like Billings's expedition itself, their trip had no practical consequences.

Meanwhile, the Siberian authorities tried to prod merchant capital toward development of the Arctic regions of Alaska. Thus in 1790 the future governor of Russian America, Alexander Baranov, upon sailing to Kodiak Island-the centre of Russian settlement in America-received secret instructions from the head of the Port of Okhotsk, I.G. Kokh. They indicated the need to expand the possessions of the empire not only along the American shore to the southeast from Kodiak (Qikertaq), but also to the north from there to Bering Strait (Tikhmenev, 1863, II, Append, pp. 29-30). Similar plans were also initiated by Baranov's employer, the wellknown merchant Grigorii Shelikhov, who founded the first permanent Russian settlement on Kodiak in 1784. Probably both Shelikhov and Kokh had in mind the establishment of Russian control over the strategically important strait between the two oceans.

The concern of tsarist authorities, the Siberian administration, and representatives of merchant capital with regard to a potential "English threat" in the North Pacific was somewhat exaggerated. Captain Cook in fact paved the way for his countrymen to arrive at the shores of northwestern America, and some English trading ships sometimes appeared near the Aleutian Islands and the shores of South and Southeast Alaska. However, the British did not make a serious attempt to secure these territories for themselves. Some members of English trading expeditions did not limit themselves to the purchase of furs from the local Indigenous people, but also left special signs on the shore to demonstrate ownership of these lands by Great Britain (Black, 2004, p. 123). It did not exceed symbolic gestures, and most British skippers were not concerned with big policy questions but rather with acquiring valuable furs for subsequent resale in China. They did this primarily in the south of the territory, which the Russians claimed in the New World by right of first discovery by the Second Kamchatka 
Expedition ( $55^{\circ}$ north latitude). The severe natural conditions of the North and the militancy of the local Indigenous people discouraged the English. Thus in 1786, during a storm near the Commander Islands, the brig Lark of the East India Company was lost, with only two sailors surviving from a crew of seventy men (Shelikhov, 1971, p. 53; Howey, 1973, p. 4). In this same year, according to a report of the Irkutsk governor general Ivan Pil, Chugach Eskimos seized an English ship and killed the whole crew. It was evidently the small brig Sea Otter (Captain William Tipping), which disappeared without a trace in the fall of 1786 in the region of Prince William Sound (Russkie otkrytiya, 1948, pp. 306-307; Dixon, 1968,p. XIX). In addition, in the North the British faced the competition of the Russians who forbade those Indigenous peoples (Aleuts, southern Eskimos, and Denaina Indians) who were under the control of the Russian-American Company (RAC) to sell furs to foreigners and to sell only to the RAC (RGIA. F .1374. Op. 3. D. 2462. L. 23 ob.). Finally, American maritime traders were becoming even more dangerous competitors. By the end of the eighteenth century they had almost completely displaced the English on the Northwest Coast of America. The predominance of Americans was explained by the fact that English skippers had to purchase licences to trade from the South Sea Company, which overtook British commerce in the Pacific. They also had to purchase licences from the East India Company, which had monopolized English trade with the East. The licences were expensive and allowed only the sale of American furs to China; they did not allow the import of Chinese wares into England. The Canadian historian James Gibson has noted that even the powerful Hudson's Bay Company (HBC), which traded in Canada (Gibson, 1976, p. 155), was unable to eliminate this double licence blockade.

Because of such circumstances the appearance of numerous English trading ships far north near the barren Arctic shores of Alaska was clearly not expected. British government expeditions also avoided the high latitudes in the eighteenth century. In particular, two ships of Captain George Vancouver's British fleet visited South and Southeast Alaska in April-June 1794, but unlike Cook's expedition, did not go up to Bering Strait. Vancouver's main goal was to map in detail the whole Northwest Coast from California in the south to the Kenai Peninsula (Yaghanen) in Alaska. He also hoped to resolve territorial disputes with the Spanish for the region around Nootka Sound (Mowichat), which is on Vancouver 
Island, located on the Pacific coast of modern Canada. The members of Vancouver's British expedition treated the Russians they encountered in Alaska rather cordially (see Vancouver, 1833, pp. 438-440; Tikhmenev, 1863 II, pp. 65-67). Meanwhile, the Russians themselves regarded the activities of the English on the Northwest Coast with great suspicion, especially after British traders temporarily established themselves in Nootka Sound.

This bay became the coveted goal of Alexander Baranov, who strove to connect the Russian colonies in South Alaska with Nootka Sound by a chain of outposts. In 1798 Baranov sent Second Lieutenant Gavriil Talin on the brig Orel to investigate and map the channels of the Alexander Archipelago to Bucareli Bay on Prince of Wales Island. He was supposed to place "secret state signs" there (metal plates with the inscription "Land of Russian Possession") and, as Baranov wrote, "with which to prevent further enterprise of the English nation in that region" (AVPRI. F. RAK. Op. 888. D. 121. L. 2 ob.).

Simultaneously the company managers commanded Baranov to send a ship to establish a settlement in Bering Strait; he was unable to follow this directive because of an insufficient number of ships. He wrote to his superiors, not without irony, that to proclaim ambitious projects on paper was not the same as bringing them to life (AVPRI. F. RAK. Op. 888. D. 121. L. 3 ob., 5, 7, 20 ob., 23-25). It is evident that the company owners intended to take over control of the Bering Strait region- not so much owing to a hypothetical confrontation with the English as an attempt to stop the leak of valuable furs from Alaska to Chukotka. There they fell into the hands of Kolyma merchants. In 1798 they sent the titular counsellor, the Dane Ivan Banner, from Okhotsk on the galliot Predpriyatie Sv. Aleksandry to establish a new settlement near Bering Strait. En route Banner wintered over in the Kurils and then continued to the Aleutian island of Unalaska (Nawan-Alaxsxa), where the local manager Emel'yan Larionov decided to cancel Banner's expedition to the north and send him to Kodiak to help Baranov (Khlebnikov, 1835, p. 65).

In 1799, when the monopolistic Russian-American Company (RAC) was formed from the conglomerate of different merchant associations under the aegis of the state, its directors, as well as Baranov in Alaska (in 1802 he officially became governor of Russian America), clearly preferred a southern direction for expansion. The economic stimulus was decisive: 
the sea otter was not found north of the Alaska Peninsula and, indeed, it was their hides that were valued above all in the fur markets of China and Russia. Depletion of the sea otter population where there had previously been intensive hunting - in the Aleutian Islands and at the shores of South Alaska-in fact forced the Russians to move southeast along the American coast to California where the sea otters had not yet completely disappeared. Political and patriotic factors played a definitive role: the RAC directors and Baranov intended to move the boundary of Russian settlements maximally south in order to claim for Russia as much land as possible despite English claims. In secret instructions to Baranov in April 1802, the RAC directors ordered him to suspend all northern operations and concentrate all his attention to the south (Rossiisko-Amerikanskaya kompaniya, 1994, pp. 34-35).

However, the tsarist government in the person of Minister of Commerce Count N.P. Rumyantsev, who supervised the RAC, felt differently at that time-clearly afraid to confront the "Mistress of the Sea" (the British Empire) at the American coast, where there was neither a Russian military garrison nor warships of the empire. Rumyantsev directly indicated this in instructions of 10 July 1803 to the unofficial head of the RAC, Chamberlain Nikolai Rezanov, before Rezanov's departure to the Russian colonies (Khlebnikov, 1835, p. 77).

Incidentally, Rumyantsev's fear of potential conflict with the British on the distant Pacific fringes lacked serious foundations. The English, occupied in conflict with Napoleon in Europe and caring for their colonies in other parts of the world, were clearly not up to contesting the Russians on the Northwest Coast of America, let alone in the American Arctic. But Rumyantsev, on the contrary, revealed a clear interest in this region in a message to Rezanov in April 1805 (Rossiisko-Amerikanskaya kompaniya, 1994, p. 119).

For his part, Rezanov did not share this interest at all and, instead of Bering Strait, set off in 1806 to sunny California to purchase food for the future colonial centre of Russian America-Novo-Arkhangel'sk. It had been founded in 1804 on Sitkha (now Baranof) Island. Rezanov planned to join fertile California to Russian possessions, and indeed he totally detested the cold Arctic coast. Upon returning to St. Petersburg from Russian America, Rezanov became seriously ill and died in Krasnoyarsk in March 1807. 
Rumyantsev, who headed the Russian Ministry of Foreign Affairs this same year, was himself no longer ready to investigate the American Arctic due to the ongoing series of wars into which the empire had been drawn as well as into intense diplomatic activity. Only in August 1814, after Rumyantsev had retired, did he again return to the idea of studying the Bering Strait region. In 1815-1818 he personally financed the roundthe-world expedition of the brig Ryurik under the command of Otto von Kotzebue, who was to attempt to find a sea route from the shores of Alaska to the Atlantic. The expedition visited Russian America in 1816-1817 and twice reached the Arctic Ocean through Bering Strait. A bay (Qikiqtagruk) was discovered north of the strait and named in honour of Kotzebue. However, the expedition was unable to achieve its main mission. The captain fell seriously ill and in 1818 the Ryurik returned to St. Petersburg with a huge amount of valuable scientific material (Kotzebue, 2014, pp. 53-352; Chamisso, 1986; Pasetskii, 1974, pp. 61-65).

Kotzebue's voyage in Arctic waters did not escape the watchful eye of the British Admiralty, which recognized the Russians as dangerous competitors in the search for the Northwest Passage (Kirwan, 1959, p. 76). Especially active was John Barrow, the Second Secretary of the Admiralty and a member of the Royal Society. From 1818 to 1845 Barrow organized thirteen Arctic expeditions. In 1818 he sent two ships commanded by David Buchan and John Franklin to Spitsbergen, Norway. The purpose was to pass from there through the North Pole to Bering Strait. Another two ships, under the direction of John Ross and William Parry, travelled to study the Canadian Arctic Archipelago, moving far to the northwest. But heavy pack ice prevented completion of both expeditions. The ships could not break through to Bering Strait and enter the Pacific Ocean (Magidovich, 1985, pp. 191-195; Pasetskii, 1974, p. 108). During the nineteenth century it was simply a technical impossibility. Only in 19031906 was the outstanding Norwegian traveller Roald Amundsen able to accomplish such a passage on the whaling yacht Gjøa. (By 2009 the region of the Arctic sea ice was reduced to a minimum by climate change. Finally, the Northwest Passage is potentially navigable by conventional ships.)

But the severe Arctic nature of the nineteenth century could not stop the stubborn British. In May 1819 a new maritime expedition set off from England in two ships, the Hecla and the Griper. Led by Parry, the Griper managed to penetrate the very heart of the Canadian Arctic 
Archipelago to Melville Island, where he wintered over before returning to the homeland in 1820. Parry subsequently led two more Arctic expeditions (in 1821-1823 and 1824-1825), but neither attained the assigned goalto pass by a sea route from the Atlantic to the Pacific Ocean (Magidovich, 1985, pp. 192-194; Pasetskii, 1974, pp. 109-110).

The Russians, too, undertook specific steps toward the study of the American Arctic. After Kotzebue's maritime expedition, Rumyantsev helped finance Petr Korsakovskii's land expedition in 1818 to the coast of Bristol Bay (Iilgayaq) and the middle course of the Kuskokwim River (Dichinanek'). They later showed strong interest in Russian geographical research in the New World. The Russian-American Company refocused its interest on the North and on interior regions of the mainland-the latter in connection with the depletion of the sea otter population on the Northwest Coast of America and the shores of California. The company hoped to improve its economic state by procuring hides of land animals, primarily beavers. Captain Lieutenant Leontii von Hagemeister, who replaced A.A. Baranov as governor of Russian America, sent Korsakovskii to the north and recommended that members of a future expedition go to Kotzebue Sound (Rossiisko-Amerikanskaya kompaniya, 2005, p. 32). But neither could advance so far north in 1818 or 1819.

The Russian Naval Fleet, in addition to the philanthropist Rumyantsev and the Russian-American Company, ultimately showed interest in polar discoveries in the American Arctic. In the summer of 1819 two naval sloops - under the command of Captain Lieutenants Mikhail Vasil'ev and Gleb Shishmarëv, a member of O.E. von Kotzebue's expedition on the brig Ryurik - were sent from Kronstadt to seek out a route from the Pacific Ocean to the Atlantic. In 1820 the Russian sailors went up to $71^{\circ} 06^{\prime}$ north latitude, which was $35 \mathrm{kms}$ north of the point Cook had reached, but farther northern movement was blocked by solid ice. They repeated the attempt the following year but were no more successful. However, Vasil'ev did succeed in discovering large Nunivak Island. Proceeding into the Chukchi Sea, he described the American shore between Cape Lisburne (Uivaq Ungasiktoq) and Icy Cape (at 70'20' north latitude) but had to turn back because of impassable ice. In early August 1822 the ships returned to Kronstadt, having completed a round-the-world voyage (Zubov, 1954, pp. 239-242; Pasetskii, 1974, pp. 71-76; see also Lazarev, 1950). This was the 
only serious attempt by naval mariners to traverse the Northwest Passage to the Atlantic.

Along with Vasil'ev-Shishmarëv's expedition, two RAC ships-the brig Golownin and the cutter Baranov, under the command of Vasilii Khromchenko and navigator Adol'f Etolin-visited the west coast of Alaska. However, almost all their investigations took place south of the Arctic zone. They failed to make notable geographic discoveries or find the mythical Russian settlement in the American north that Rumyantsev had insisted on. Ultimately all such searches ceased (RGAVMF. F. 14. Op. 1. D. 187. L. 3-4; Burykin, 1985; Pasetskii, 1974, pp. 103-105).

The conclusion of these expeditions coincided with the worsening of Anglo-Russian relations brought on by publication of Emperor Alexander I's royal decree on 4 September 1821. In this decree, Russia claimed the Northwest Coast of America to $51^{\circ}$ north latitude and prohibited foreign ships from approaching closer than $161 \mathrm{~km}$ to the Russian colonies in the New World (PSZRI, 1830, XXXVII, pp. 823-832). The decree trying to expel foreign competitors, adopted through active lobbying by the RAC led, on one hand, to the sharp diplomatic reaction of the United States and Great Britain and, on the other, to aggravation of the food deficit in Russian America. The RAC board of directors in St. Petersburg lacked the ability to supply the colonies by ships sent from the Baltic. After long diplomatic debates, the tsarist government concluded conventions with the United States and Great Britain in 1824 and 1825 regarding free access to the Russian colonies by their ships for the following ten years. These same conventions determined the southern boundary of Russian possessions at $54^{\circ} 40^{\prime}$ north latitude (instead of $51^{\circ}$ ) and drew the eastern boundary along the coastal ridge of the Rocky Mountains from Portland Canal in the south to $141^{\circ}$ west longitude (PSZRI, 1830, XXXIX, pp. 251-253; PSZRI, 1830, XL, pp. 72-74). Furthermore, the Russians permitted the English eternal right to navigate those rivers flowing through the territory of Russian America, which have their source in British lands of neighbouring Canada? Ironically, this article limited Russian sovereignty in its own colonies and subsequent responsibility for the so-called Stikine Incident of 1834. And behind the British Ministry of Foreign Affairs, which acquired from St. Petersburg significant concessions in the territorial question, the Hudson's Bay Company was clearly visible. As the American historian J.S. Galbraith noted, the diplomatic struggle 
surrounding the decree of 1821 was not simply about the boundary and freedom of navigation along the shores of northwestern America. In reality it reflected the conflict between the Russian-American Company and the Hudson's Bay Company for the fur resources of the still-undeveloped territories (Galbraith, 1957, p. 120).

After agreeing on delineation of possessions between Russia and Great Britain in North America in 1825, Anglo-Russian rivalry had moved from the political, strategic military, and territorial arena entirely to the sphere of economic and geographical discoveries. In both cases the Russians clearly yielded to the British. Thus, N.P. Rumyantsev's intended polar expedition from Russian America to the Mackenzie River in Canada-on which Rumyantsev was ready to spend 20,000 of his own rubles-was halted by the patron's death. Also cancelled was the secret maritime expedition planned by the Maritime Ministry to continue investigation beyond Bering Strait in the American Arctic (Pasetskii, 1974, pp. 118-119). In 1825 Lieutenant V.P. Romanov proposed in the open press (Romanov, 1825) a land expedition through the valley of the Copper River to the Arctic Ocean and Hudson Bay. Neither the tsarist government nor the leadership of the Russian-American Company lent their support.

The British, by contrast, took several energetic steps to conclude investigation of the shores of the American Arctic. Besides maritime expeditions under Parry's command, they chose to use land expeditions to study the coast of northern Canada and Alaska. They now had the experience offered by such trips since, at the end of the eighteenth century (17701772), English naval sailor Samuel Hearne became the first European to cross northeastern Canada on foot. Hearne reached the Arctic Ocean at the mouth of the Coppermine River, having found no Northwest Passage in the lower latitudes. The Scottish explorer Alexander Mackenzie descended to the coast of the Arctic Ocean along the large river named after him (see Mackenzie, 1808). With the dawn of the 1820s, Captain John Franklin picked up the baton. He wondered about the possible prospects of Russian possessions expanding into the fur-rich basin of the Mackenzie River (Deb-Cho) (Postnikov, 2000, p. 256). In 1825-1827 Franklin completed a boat trip along the Arctic coast to $600 \mathrm{~km}$ west from the mouth of the Mackenzie River, and to Prudhoe Bay in the territory of Alaska, where the twentieth century yielded the discovery of huge oil reserves. The English travellers saw among the local Indigenous people a lot of goods of Russian 
origin that had reached them from Chukotka by means of barter. The English government sent the maritime expedition of Captain Frederick Beechey (1825-1828) on the naval sloop Blossom toward Franklin through Bering Strait. This was the second British expedition, after those of Captain Cook, on which the English undertook an attempt to pass from the west to the Atlantic. Finding no signs of Franklin's presence in Kotzebue Sound on Chamisso Island (Iguagrik), which was the designated meeting place, Beechey sent a sailing longboat under the command of Thomas Elson, who in August 1826 reached the northernmost point of Alaska-Point Barrow ( $71^{\circ} 23^{\prime}$ north latitude). Heavy ice blocked English movement farther east. Just $235 \mathrm{~km}$ to the east, the Franklin expedition also had to turn back. In August 1827 Beechey again passed through Bering Strait to resume Arctic exploration, but the ice was even worse than in the preceding year. The longboat crews again turned east along the coast of Alaska to search for the Franklin expedition. They found no traces of him. On its return trip to the ship the longboat was wrecked and three English sailors were lost. Beechey was forced by circumstances to return to England in 1828 (Magidovich, 1985, pp. 195-198; Postnikov, 2000, pp. 257-262; Khlebnikov, 1979, pp. 73, 228; Beechey, 1831).

Russia's "answer" to the trips of Captains Franklin and Beechey was to equip, in 1826, a detachment of two naval sloops-the Moller (Captain Lieutenant M.N. Stanyukovich) and the Senyavin (Captain Lieutenant F.P. Litke) — to the North Pacific. However, the commanders' sloops did not have tasks of political significance or investigation of unknown lands. The main goal of the maritime expedition was rather simple: the delivery of cargo from Kronstadt to Kamchatka and to Russian America, as well as a hydrographic inventory of the Bering Sea shores in 1827-1828 (Litke, 1948; Zubov, 1954, pp. 255-257; Pasetskii, 1974, pp. 120-124).

Upon conclusion of this expedition, all the geographical research in the American Arctic fell squarely on the shoulders of the RussianAmerican Company, which in 1829-1830 first sent an ensign of the Corps of Fleet Navigators (CFN), Ivan Vasil'ev, to investigate the basin of the Nushagak and Kuskokwim rivers, followed in 1830 by Midshipman A. K. Etolin to the Bering Strait region on the brig Chichagov. Etolin examined Norton Sound, St. Lawrence Island, and Chukotka, where he traded with the local residents (Tikhmenev, 1863, I, pp. 283-285). Vasil'ev's and Etolin's expeditions served as a prologue for more intense penetration of 
the Russians into the North and in the beaver-rich interior regions of the mainland.

At the same time, the English clung to their ambitious plans to navigate the Northwest Passage. In 1829, backed by the London magnate Felix Booth, John Ross led the next expedition on the private steamship Victory. The latest attempt to break through the ice of the Canadian Arctic to reach Alaska failed. Not until 1833 were the remains of the Ross expedition, which before this had been to the Earth's magnetic pole, rescued from Lancaster Sound (Tallurutiup Imanga) (Pasetskii, 1974, p. 125; Potter, 2005, p. 1775). This failure cooled British research fervour for a decade.

During this period the Russians were not preoccupied with their rivalry with the English for new discoveries in the American Arctic. They were driven by more practical motives. In 1831 the Russian-American Company board of directors recommended that the governor of Russian America, Baron Ferdinand von Wrangell, establish a trading post on the sea coast in the Bering Strait region-in this case, company ships could visit the Chukchi on the opposite shore of Asia in order to develop the fur trade there (NARS, RG 261. RRAC. Roll 7, pp. 178-179). Guided by these considerations, Wrangell ordered a ship, commanded by Mikhail Teben'kov, be sent in 1832 to Bering Strait to select a suitable location for a settlement and trade with the Indigenous people (Rossiisko-Amerikanskaya kompaniya, 2005, p. 252). In the spring of 1833 F.P. Wrangell again directed two ships to the Bering Strait region- the Kvikhpak and the Urup, under the commands of Lieutenants N.Ya. Rozenberg and M.D. Teben'kov. The governor directed the latter to construct a company trading post there. Teben'kov fulfilled Wrangell's assignment and in summer 1833 founded a new fortified outpost in Norton Sound, named "St. Mikhail Redoubt," which later served as the base for Arctic and Subarctic RAC expeditions (Tikhmenev, 1863, I, pp. 285-286).

During this period the two fur-trading monopolies-the RussianAmerican Company and the Hudson's Bay Company-began to engage in direct competition. Movement of the English trading posts ever closer to the southeastern boundary of Russian America ultimately provoked the so-called Stikine Incident in 1834, when HBC agents tried to sail past the Russians' Dionisievskii Redoubt at the mouth of the Stikine River in order to establish a new trading post upstream beyond the Canadian border. The Russians blocked passage despite the relevant 
article of the 1825 convention, thus provoking a diplomatic scandal and sharply aggravating Russian-British relations (Barratt, 1983, pp. 26-35; Jackson, 1967). Though the RAC and HBC amicably settled the conflict in 1838-1839, the Stikine Incident nevertheless indirectly intensified both companies' geographic reconnaissance during the second half of the 1830s. Thus HBC agents Peter Dease and Thomas Simpson investigated the coast of the Arctic Ocean in 1837, reaching Point Barrow (Nuvuk) in the west of the Russian America territory and ultimately mapping the entire mainland coast of the American Arctic (Postnikov, 2000, pp. 262-266; Dease and Simpson, 1838; Simpson, 1843, pp. 127-167; Okonchatel'noe obozrenie, 1839). The RAC reacted a year later, sending a baidara expedition under the command of second lieutenant of the CFN Aleksandr Kashevarov, who investigated and described the American coast of the Arctic Ocean from Cape Lisburne to Point Barrow (Kashevarov, 1840; Postnikov, 2000, pp. 310-314). A year later, in March 1839, navigator Pëtr Malakhov reached the mouth of the Nulato River, which empties into the Yukon River, where an RAC outpost by the same name emerged. The "Nulato outpost," or simply Nulato, became the RAC's northernmost settlement, located approximately $180 \mathrm{~km}$ south of the Arctic Circle.

It was from Nulato that the well-known traveller Lieutenant Lavrentii Zagoskin set off in February 1843, trying to make his way from the Yukon to the Arctic sea coast in Kotzebue Sound. However, his attempt ultimately failed (Zagoskin, 1956, pp. 137-145). After Zagoskin's investigations the $\mathrm{RAC}$ was forced to abandon the project of founding an outpost on the shore of Kotzebue Sound because of the extremely severe climate north of Bering Strait and the heavy ice, which often blocked the route of ships and would have made supplying the planned trading post very difficult (Zagoskin, 1956, pp. 41, 182). This outpost was subsequently supposed to stop the leakage of furs from Alaska to the Chukchi in Asia. The Chukchi sold the furs to Siberian merchants and to American whalers who had begun to actively hunt in the Bering and Chukchi Seas in those years (Ray, 1992, pp. 121-141).

Whereas the Russians tried to concentrate on the economic exploitation of the Arctic territories of Alaska and ceased rivalry with the British in the sphere of geographical exploration, the latter tried ultimately to strengthen for itself priority over a northwestern sea passage. In 1845 John Franklin set off from England in two ships on his third polar voyage; 
the voyage was fatal for him and his companions. The fearless captain managed to move into the central part of the Canadian Archipelago, where his ships became locked in the ice and all the people perished from cold, hunger, and scurvy (some of them tried unsuccessfully to reach the mainland shore on foot). The disappearance of the Franklin expedition brought on an unprecedented search and rescue campaign when the British Admiralty and private individuals sent to the Arctic more than a dozen expeditions in 1847-1859 (see Ross 2002). Some of the search ships were sent from the Atlantic Ocean, others from the Pacific. Robert McClure - the captain of one of these ships-emerged as the first to pass through the Northwest Passage during an expedition of 1850-1854. First, he guided his ship the Investigator from the Pacific Ocean through Bering Strait into the Beaufort Sea. After wintering over at the western islands of the Canadian Arctic Archipelago, he was forced to leave the ship frozen in the ice and move east until he encountered a detachment from another English expedition sent in search of Franklin, with which he returned to England (Stein, 2015). In general, the fate of Franklin and his comrades, and equally the dramatic story of their search, continues even now to excite the imagination of historians (see Stein, 2015; Hutchinson, 2017; Walpole, 2017).

The appearance of British ships at the Arctic shores of Alaska caused mild anxiety for the RAC administration, which traditionally treated foreigners with suspicion, though it did provide some assistance to the English in searching for traces of the Franklin expedition in its territory. The Russians had a specific reason for negative relations with the British. The HBC by this time had expanded its trade operations to the Yukon River, where in 1847, not far from its confluence with the Porcupine River (Chôonjik), the English constructed Fort Yukon, now in lands of Russian America west of $141^{\circ}$ west longitude and directly at the boundary of the Arctic Circle. The founder of this trading post, Alexander Murray, realized that it was in foreign territory but decided not to retreat until the Russians filed an official protest. The Russians declined to protest although one of the RAC's employees, Ivan Lukin, twice visited Fort Yukon, in 1862 and 1866 (Galbraith, 1957, pp. 159-160; Arndt, 1990, pp. 105-106). The Russian-American Company did not want to aggravate relations with the Hudson's Bay Company, due to the agreement under which the Russian 
colonies had been declared neutral during the Crimean War and saved from ruin by an Anglo-French squadron.

From the day of its founding, Fort Yukon began to attract Indigenous people (Gwich'in and others) from the Yukon River valley-including from Russian territory, since the English paid more for furs than the Russians and the quality of their wares was higher. It was no accident that in the nineteenth century Britain was called the "workshop of the world." The Russian-American Company was also incapable of competing with the English on an equal footing because its transportation costs were two to three times higher (Gibson, 1976, p. 200; Whymper, 1966, p. 189, 225). It comes as no surprise that in the Anglo-Russian economic confrontation in the Arctic zone of Alaska the HBC clearly predominated over its rival. Under these circumstances the RAC was forced to limit itself to sending small trading expeditions in baidary from Nulato up the Yukon, only to the region of its confluence with the Tanana (approximately midway between Fort Yukon and Nulato). Parties of HBC agents from Fort Yukon periodically arrived here with similar goals (Turck and Lehman Turck, 1992, pp. 53-54,58). However, both sides avoided contact with each other, evidently fearing possible conflicts that neither side wanted. And this situation was preserved right up to the sale of Alaska to the United States in 1867.

In summary, it is possible to draw the following conclusions. AngloRussian rivalry in the American Arctic was really limited exclusively to the circumpolar regions of Alaska. Its beginning is associated with the third round-the-world expedition of Captain James Cook (1778), though prior to this the English had repeatedly tried over the centuries to penetrate the American Arctic and go through the Northwest Passage to the Pacific Ocean, on whose eastern shores the Russians had settled since the midseventeenth century. Subsequent territorial expansion of the British and Russian empires in the eighteenth century would sooner or later inevitably lead both powers into conflict over their interests in the northwestern part of North America, including the Arctic zone. Still, Anglo-Russian rivalry in this region avoided open military conflict and, rather, was limited to rare periods of political-diplomatic confrontation (whose sources were usually far from the Arctic), competition in the field of geographic discoveries, and relatively insignificant economic competition. In all these spheres the British definitely dominated. The reasons lay in the superiority of 
capitalistic England over tsarist Russia with its backward socio-economic and political structure. The inequality was amplified by the domination of the British military and merchant fleets on the seas, which figured decisively in supplying and protecting transoceanic colonies. Therefore the Russians, by selling Alaska to the United States, implicitly wanted to transform its rivalry with its main geopolitical opponent into an AngloAmerican confrontation, and ideally provoke a war over British Canada (Rossiisko-Amerikanskaya kompaniya, 2010, p. 398; Jensen, 1975, p. 20, 5859). There were specific reasons for this, since during the recently ended Civil War in the United States the English were entirely on the side of the southern Confederates. British diplomacy and political circles promptly reacted to the impending threat to Canada and in 1867, just three months after Russia ceded Alaska to the United States, England granted Canada its formal independence in status as a dominion of the British Empire.

\section{Archival Documents}

AVPRI-Arkhiv vneshnei politiki Rossiiskoi imperii [Archive of Foreign Affairs of the Russian Empire]. F. RAK. Op. 888. D. 121.

AVPRI. F. Snosheniya Rossii s Angliei [Contacts between Russia and England]. Op. 356. D. 507.

NARS-National Archives and Record Service, Washington. RG 261. RRAC. Roll 7.

PSZRI-Polnoe sobranie zakonov Rossiiskoi imperii [Complete Collection of Laws of the Russian Empire]. St. Petersburg: Tip. II Otdeleniya sobstvennoi E. I. V. Kantselyarii, 1830, vols. XXXVII, XXXIX, XL.

RGIA-Rossiiskii gos. istoricheskii arkhiv [Russian State Historical Archive]. F. 1374. Op. 3. D. 2462.

RGAVMF-Rossiiskii gos. Arkhiv Voenno-morskogo flota [Russian State Archive of the Naval Fleet]. F. 14. Op. 1. D. 187.

\section{References}

Arndt, K. L. (1990). Russian exploration and trade in Alaska's interior. In B. S. Smith and R. J. Barnett (Eds.), Russian America: The Forgotten Frontier (pp. 95-108). Tacoma: Washington State Historical Society.

Barr, W. (2005) Middleton, Christopher. In M. Nuttall (Ed.), Encyclopedia of the Arctic 2, 1294-1295. New York and London: Routledge. 
Barratt, G. (1983). Russian Shadows on the British Northwest Coast of North America, 1810-1890. Vancouver: University of British Columbia Press.

Beechey, F. W. (1831). Narrative of a voyage to the Pacific and Beering's strait, to cooperate with the polar expeditions: performed in His Majesty's ship Blossom, under the command of Captain F.W. Beechey ... in the years 1825, 26, 27, 28 ... (vol.1). London: H. Colburn and R. Bentley.

Black, L. T. (2004). Russians in Alaska 1732-1867. Fairbanks, Alaska: University of Alaska Press.

Burykin, A. F. (1985). Plavanie V. S. Khromchenko k Severo-zapadnym beregam Ameriki [Voyage of V.S. Khromchenko to the Northwest Shores of America]. Letopis'Severa, 11, 162-174.

Cook (see Kuk).

Dease, R. W., and Simpson, P. (1838). An account of the recent Arctic discoveries by Messers Dease and T. Simpson. Journal of the Royal Geographical Society, 8 , 213-225.

Dixon, G. A. (1968). A Voyage round the World: But More Particularly to the NorthWest Coast of America: Performed in 1785, 1786, 1787, and 1788, in the King George and Queen Charlotte, Captains Portlock and Dixon. New York: Da Capo Press.

Efimov, V. A. (1948). Iz istorii russkikh ekspeditsii na Tikhom okeane. Pervaya polovina XVIII veka [From the History of Russian Expeditions in the Pacific Ocean. First Half of the $18^{\text {th }}$ Century]. Moscow: Voennoe izd-vo Min-va Vooruzhennykh Sil SSSR.

Galbraith, J. S. (1957). The Hudson's Bay Company as an imperial factor, 1821-1869. Berkeley; Los Angeles: University of California Press.

Gibson, J. R. (1976). Imperial Russia in frontier America. The changing geography of supply of Russian America, 1784-1867. New York: Oxford University Press.

Howey, F. W. (1973). In R. A. Pierce (Ed.), A list of trading vessels in the Maritime fur trade, 1785-1825. Kingston, Ontario: The Limestone Press.

Hutchinson, G. (2017). Sir John Franklin's Erebus and Terror Expedition: Lost and Found. London: Bloomsbury Publishing PLC.

Jackson, C. I. (1967). The Stikine territory lease and its relevance to the Alaska purchase. Pacific Historical Review, 3(3), 289-306.

Jensen, R.J. (1975). The Alaska purchase and Russian-American relations. Seattle and London: University of Washington Press.

Kashevarov, A. F. (1840). Obozrenie beregov Severnoi Ameriki ot mysa Barrova, sovershennoe russkoi ekspeditsieyu v $1838 \mathrm{~g}$. [Survey of the shores of North America from Point Barrow, conducted by a Russian Expedition in 1838]. Syn Otechestva [Son of the Fatherland], 1 (VII), 127-144. 
Khlebnikov, K. T. (1835). Zhizneopisanie Aleksandra Andreevicha Baranova, Glavnogo pravitelya Rossiiskikb kolonii v Amerike [Biography of Alexander Andreevich Baranov, Chief Director of the Russian Colonies in America]. St. Petersburg: V Morskoi tip.

Khlebnikov, K. T. (1979). Russkaya Amerika v neopublikovannykb zapiskakb K. T. Khlebnikova [Russian America in the unpublished notes of K. T. Khlebnikov]. Compiled, introduced, and annotated by R. G. Lyapunova and S. G. Fedorova. Leningrad: Nauka.

Kirwan, L. P. (1959). The white road: A survey of polar exploration. London: Hollis $\&$ Carter.

Kotsebu [Kotzebue], O. E. von. (2014). Puteshestvie vokrug sveta. Izdanie vtoroe [Voyage Around the World. Second Edition]. Moscow: Eksmo.

Kuk, Dzh. (Cook, John). (1971). Tret'e plavanie kapitana Dzheimsa Kuka. Plavanie $v$ Tikhom Okeane v 1776-1780 gg. [The third voyage of Captain James Cook. A voyage in the Pacific Ocean in 1776-1780]. Trans. from English, intro. to article, and commentary by Ya. M. Svet. Moscow: Mysl'.

Lazarev, Al. P. (1950). Zapiski o plavanii voennogo shlyupa Blagonamerennogo v Beringov proliv $i$ vokrug sveta dlya otkrytii v 1819, 1820, 1821 i 1822 godakh, vedennye grvardeiskogo ekipazha leitenantom $A$. P. Lazarevym [Notes on the voyage of the naval sloop Blagonamerennyi to Bering Strait and around the world for discoveries in 1819,1820,1821, and 1822, Conducted by Guards Lieutenant A. P. Lazarev]. Ed. with introduction and commentary by A. I. Solov'ev. Moscow: Gos. izd-vo geogr. lit.

Litke (Lütke), F. P. (1948). Puteshestvie vokrug sveta na voennom shlyupe "Senyavin." 1826-1829 [Voyage around the world on the naval sloop Senyavin. 18261829]. Edited with introduction and notes by N. N. Zubov and A. D. Dobrovol'skii. Moscow: Gos. izd-vo geogr. lit.

Mackenzie, A. (1808). Puteshestviye po Severnoy Amerike $k$ Ledovitomu moryu i Tikhomu okeanu sovershennoe gospodami Khernom i Makenziem s prisovokupleniyem opisaniya: mekhovoi torgovli v Kanade proizvodimoy, vsekh zverey $v$ Amerike obitayushchikhsya, nravov i obyknovenii vnutrennikh dikikh [The journey across North America to the Arctic Sea and the Pacific Ocean was accomplished by Messrs. Hearne and Mackenzie with the addition of a description: The fur trade in Canada produced by all the animals living in America, the mores and customs of the inland savages]. SPb.: Morskaya tip.

Magidovich, I. P., and Magidovich, V. I. (1983). Ocherki po istorii geograficheskikh otkrytii. T.2. Velikie geograficheskie otkrytiya (konets $X V$-seredina XVII v.) [Essays on the history of geographical discoveries. Vol.2. Great geographical discoveries (End of the 15th to the Middle of the 17th Century)]. Moscow: Prosveshchenie. 
Magidovich, I. P., and Magidovich, V. I. (1985). Ocherki po istorii geograficheskikh otkrytii. T.4. Geograficheskie otkrytiya $i$ issledovaniya Novogo vremeni (XIXnachalo $X X$ v.) [Essays on the history of geographical discoveries. Vol.4. Geographical discoveries and explorations of the new time (19th-Early 20th century)]. Moscow: Prosveshchenie.

Okonchatel'noe obozrenie severnykh beregov Ameriki P.V.Dizom iT. Simpsonom letom i osenyu $1837 \mathrm{~g}$. [Final survey of the northern shores of America by P. W. Dease and T. Simpson in the Summer and Fall of 1837]. Syn Otechestva [Son of the Fatherland] (1839). VII: 83-114.

Pasetskii, V. M. (1974). Arkticheskie puteshestviya rossiyan [Arctic Travels of Russians]. Moscow: Mysl'.

Polevoi, B. P. (1997). "Predistoriya Russkoi Ameriki (zarozhdenie interesa v Rossii k severo-zapadnoi Amerike)” [Prehistory of Russian America (origin of interest in Russia to the north-west coast of America)]. In N. N. Bolkhovitinov (Ed.), Istoriya Russkoi Ameriki (1732-1767). T. 1. Osnovanie Russkoi Ameriki (1732-1799) [History of Russian America (1732-1767). Vol. 1. Founding of Russian America (1732-1799)] (pp. 12-50). Moscow: Mezhdunarodnye otnosheniya.

Postnikov, A. V. (2000). Russkaya Amerika v geograficheskikh opisaniyakh i na kartakh. 1741-1867 gg. [Russian America in Geographic Descriptions and on Maps. 1741-1867]. St. Petersburg: Dmitrii Bulanin.

Potter, R. A. (2005). Ross, Sir John. In M. Nuttall (Ed.), Encyclopedia of the Arctic. New York and London: Routledge, 3, 1774-1776.

Ray, D. J. (1992). The Eskimos of Bering Strait, 1650-1898. Seattle and London: University of Washington Press.

Romanov, V. P. (1825). Mysli o puteshestvii, kotoroe mozhno predprinyat' ot reki Mednoi, po sukhomu puti, do Ledovitogo morya i do Gudsonova zaliva [Thoughts on a trip that can be undertaken from the Copper River by land to the Arctic Ocean and to Hudson Bay]. Severnyi arkbiv, 18, 129-135.

Ross, W. G. (2002). The type and number of expeditions in the Franklin search, 1847-1859. Arctic, 55(1), 57-69. Retrieved from https://www.jstor.org/ stable/40512918

Rossiisko-Amerikanskaya kompaniya i izuchenie Tikhookeanskogo Severa, 1799-1815. (1994). [The Russian-American Company and the study of the North Pacific, 1799-1815]. Comp. L. I. Spiridonova, A. E. Ioffe, and N. N. Bolkhovitinov, (ed). A. L. Narochnitskii and N. N. Bolkhovitinov. Moscow: Nauka.

Rossiisko-Amerikanskaya kompaniya i izuchenie Tikhookeanskogo Severa, 1841-1867 (2005). [The Russian-American Company and the study of the North Pacific, 1841-1867]. N. N. Bolkhovitinov (Ed.). Moscow: Nauka. 
Rossiisko-Amerikanskaya kompaniya i izuchenie Tikhookeanskogo Severa, 1815-1841 (2010). [The Russian-American Company and the study of the North Pacific, 1815-1841]. A. Yu. Petrov (Ed.). Moscow: Nauka.

Russkaya Tikhookeanskaya epopeya [The Russian Pacific Ocean Epic]. (1979). Compiled by V. A. Divin et al. Khabarovsk: Khabarovskoe kn. izd-vo.

Russkie ekspeditsii po izucheniyu severnoi chasti Tikhogo okeana v pervoi polovine $X V I I I$ v. [Russian expeditions for the study of the northern part of the Pacific Ocean during the first half of the 18th century]. (1984). Comp.T. S. Fedorova, L. V. Glazunova, A. E. Ioffe, L. I. Spiridonova, chief ed. A. L. Narochnitskii. Moscow: Nauka.

Russkie ekspeditsii po izucheniyu severnoi chasti Tikhogo okeana vo vtoroi polovine $X V I I I v$. [Russian expeditions for the study of the northern part of the Pacific Ocean during the second half of the 18th Century]. (1989). Comp. T. S. Fedorova, L. V. Glazunova, and G. N. Fedorova, ed. R. V. Makarova, chief ed. A. L. Narochnitskii. Moscow: Nauka.

Russkie otkrytiya v Tikhom okeane i Severnoi Amerike v XVIII veke [Russian discoveries in the Pacific Ocean and North America in the 18th Century]. (1948). A. I. Andreev (Ed.). Moscow: Gos. izd-vo geogr. lit.

Sarychev, G. A. (1952). Puteshestvie flota kapitana Sarycheva po severo-vostochnoi chasti Sibiri, Ledovitomu moryu i Vostochnomu okeanu.... [The voyage of Fleet Captain Sarychev through the northeastern part of Siberia, the Arctic Ocean, and the Eastern Ocean .... . Moscow: Geografgiz.

Shamisso (Chamisso), A. (1986). Puteshestvie vokrug sveta [Voyage around the world]. Translated from German by A. M. Model'. Commentary and postscript by L. P. Serebryannyi. Moscow.

Shelikhov, G. I. (1971). Rossiiskogo kuptsa Grigoriya Shelikhova stranstvovaniya iz Okhotska po Vostochnomu okeanu $k$ Amerikanskim beregam [The journey of the Russian Merchant Grigorii Shelikhov from Okhotsk over the eastern ocean to the American shores]. Edited, prefaced, and annotated by B. P. Polevoi. Khabarovsk: Khabarovskoe kn. izd-vo.

Simpson, P. (1843). Narrative of the discoveries on the north coast of America: effected by the officers of the Hudson's Bay Company during the years 1836-39. London: R. Bentley.

Stein, G. M. (2015). Discovering the North-West Passage. The four-year Arctic odyssey of H.M.S. Investigator and the McClure expedition. London: McFarland \& Company, Inc. 
Tikhmenev,P.A.(1863).Istoricheskoe obozrenie obrazovaniya Rossiisko-Amerikanskoi kompanii $i$ deistvii ee do nastoyashchego vremeni [A historical review of the formation of the Russian-American Company and its activities up to the present time]. St. Petersburg: Tip. Eduarda Veimara, pt. I; pt. II.

Turck, T. J., \& Lehman Turck, D. L. (1992). Trading posts along the Yukon River: Noochuloghoyet trading post in historical context. Arctic, 45(1): 51-61.

Vancouver, G. (1833). Puteshestvie v severnuyu chast' Tikhogo okeana i vokrug sveta, sovershennoe v 1790, 1791, 1792, 1793, 1794 i 1795 godakh kapitanom Georgiem Vankuverom [Voyage of discovery of the North Pacific Ocean, and round the world carried out in the years 1790, 1791, 1792, 1793, 1794, and 1795 by Captain George Vancouver]. Translated from English. St. Petersburg: Morskaya tip., Bk. 5.

Walpole, G. (2017). Relics of the Franklin expedition: Discovering artifacts from the doomed Arctic voyage of 1845. London: McFarland \& Company, Inc.

Whymper, F. (1966). Travel and adventure in the territory of Alaska. Ann Arbor, Michigan: Xerox Company.

Zagoskin,L.A.(1956). Puteshestviya i issledovaniya leitenanta Lavrentiya Zagoskina v Russkoi Amerike v 1842-1844 gg. [Lieutenant Zagoskin's travels in Russian America, 1842-1844]. Ed., notes, commentary by M. B. Chernenko, G. A. Agranat, E. E. Blomquist. Moscow: Gos. izd-vo geogr. lit.

Zubov N. N. (1954). Domestic seafarers are explorers of the seas and oceans. Moscow: Gos. izd-vo geogr. lit.

\section{Author}

Andrei Val'terovich Grinëv is a professor in the Humanities Institute at Peter the Great St. Petersburg Polytechnic University, St. Petersburg, Russian Federation. E-mail agrinev1960@mail.ru.

\section{Acknowledgements}

The author must express his deep gratitude to Dr. Richard L. Bland for his excellent translation of this article from Russian. I would also like to thank Nan Coppock-Bland for continued assistance with editorial advice on the translations. 